\section{Determining the Permissible Longwall Face Advance in the Protective Pillar Conditioning the Liquidation of a Mining Shaft}

\author{
Ryszard Mielimąka, Henryk Kleta \\ Silesian University of Technology in Gliwice, Poland
}

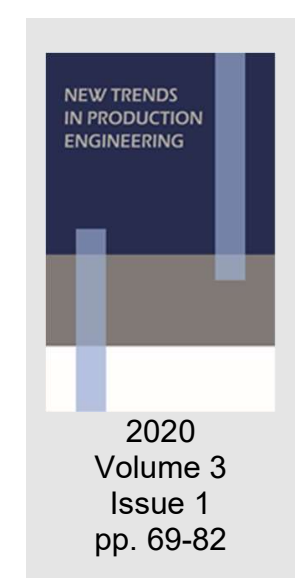

Date of submission to the Editor: 02/2020

Date of acceptance by the Editor: 03/2020

\title{
INTRODUCTION
}

In the area of shaft $X$, mining operations of the longwall 5 are carried out from west to east, which in its further run is to turn from east to west through the protective pillar at the distance of approximately $175 \mathrm{~m}$ to the north from the shaft.

Along with the mining operations of this longwall, preparatory activities are carried out for the liquidation of shaft $X$, using the backfilling method. If these preparatory activities are protracted, the mined longwall will enter the protective pillar of the shaft, and the influences caused by it may lead to a significant deformation and damage to the lining of shaft $\mathrm{X}$, as well to the deformation of shaft equipment, threatening the safety of its use. Such a condition could result in difficulties in using the shaft winding plant, and thus it could impede the ultimate preparation of the shaft for liquidation.

Bearing this in mind, it is necessary to determine the permissible face advance of the longwall No. 5, at which no damage to shaft lining and its equipment could occur and which could threaten safe liquidation of the shaft by backfilling.

\section{MINING - GEOLOGICAL AND TECHNICAL CONDITIONS OF THE SHAFT X} Shaft $X$ is an old shaft, sunk around the year 1906, and is currently being used as the material - transportation and upcast shaft. The cross-section shape of the shaft is circular with the diameter of $4.5 \mathrm{~m}$ and the depth of $454.9 \mathrm{~m}$.

The shaft along its entire depth is made in brick masonry lining, with the lining being $0.78 \mathrm{~m}$ thick to the depth of $263 \mathrm{~m}$, and $0.51 \mathrm{~m}$ thick below that depth. The shaft has one four-deck cage and one skip for long materials, e.g. pipelines, power cables or signaling cables.

The area of shaft $X$ contains Quaternary, Neogene and Carboniferous formations. The thickness of the Quaternary formations in the area of shaft $X$ is about $18.8 \mathrm{~m}$, and they are represented by Pleistocene formations of fluvioglacial origin. The said formations comprise mainly sands interlayered with silts and loams. Below, to the depth of about $185.0 \mathrm{~m}$ there are layers 
of Neogene formations represented mainly by gray-greenish loams, locally ashy-gray and dark gray, mainly plastic ones. From the depth of $121.2 \mathrm{~m}$ to $138 \mathrm{~m}$ below ground level in the profile of Neogene formations there are layers of gray, compact, lump gypsum, in some places crystal. Below them, i.e. between the depth of $138 \mathrm{~m}$ and $185.0 \mathrm{~m}$, thin-layered limey gypsum and lumps of crystal gypsum are found, as well as gray and gray-greenish limey loams.

At the contact with the Carboniferous formation there is a weathered zone, where there are various-grained sands, thin layers of coals, loam shales and Carboniferous shales under the variegated loams.

Carboniferous formations in the shaft X start from the depth of about $190.0 \mathrm{~m}$, in the form of Rudzkie layers, which are mostly represented by loamy-sandy shales and claystones with varying degrees of sand content, and by sandstones interlayered with coal deposits. Sandstones are usually light-gray, fine and medium grained. Coal deposits are usually surrounded by claystones and loamy-sandy stones, less often by sandstones. They are often separated into several layers divided by intermediate bands of claystone.

In the original hydrogeological conditions, Carboniferous aquifers were very rich and well-developed. However, the impacts of mining operations to date have changed the hydrogeological conditions. Aquifer waters have been almost completely drained as a result of over 110 years of drainage. Currently, in terms of waterlogging, most of the shaft is dry, moisture caused by water seepage through the lining is observed only within the depth range of $46-150 \mathrm{~m}$ and in the area approximately $195 \mathrm{~m}$ deep.

Presently, along the entire length of the shaft, there is no damage to the lining that may indicate excessive load on the lining, and the lining does not show any major corrosion losses. Only in some places, on individual bricks, surface defects of up to $5 \mathrm{~cm}$ deep are visible, as well as mortar losses on joints between the bricks up to $3 \mathrm{~cm}$ deep. In the area of the inlet of the liquidated ventilation duct, on the north-east side, there is a vertical crack in the lining, about $3 \mathrm{~m}$ long. Glass fillings were applied on the said damage in the lining (Fig. 1).

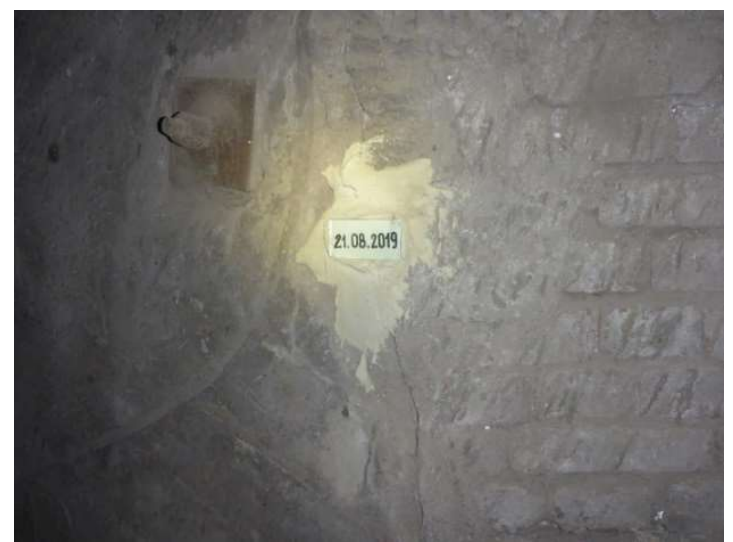

Fig. 1 Vertical crack in the inlet area of the ventilation duct with a applied filling

The technical condition of the lining of shaft $X$ can be assessed as good (Fig. 2), which is indisputably beneficial due to the deformations which will 
effected by mining operations of the longwall predicted for the protective pillar of the shaft.

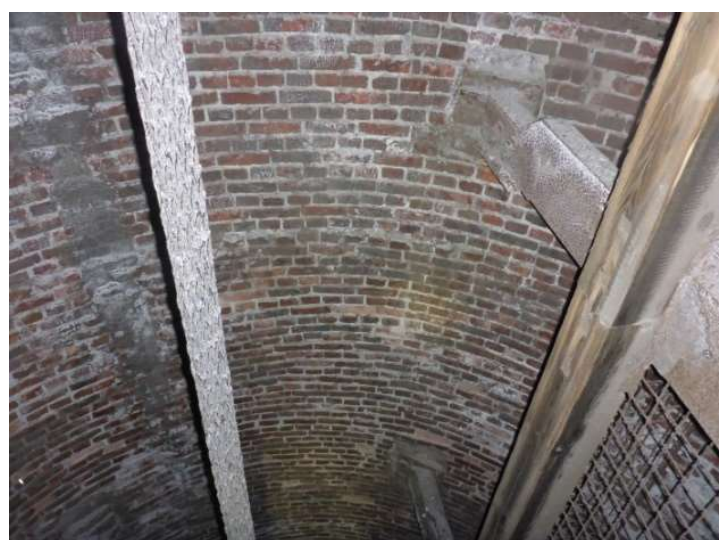

Fig. 2 Lining of shaft $X$ at the depth of about $300 \mathrm{~m}$

In the past, intensive mining operation was conducted in the area of the protection pillar of shaft $X$. To date 109 longwalls in 26 deposits and seams have been extracted in the area of the protective pillar of shaft $\mathrm{X}$, up to the distance of about $1200 \mathrm{~m}$ from it, namely: 405/1. 405/3, 406/1, 406/3, 407/1, 407/2, 407/3, 408/1, 408/2, 408/2I, 408/2II, 408/3, 412, 414/3, 415/2, 415/4, 415/5, 416, 501, 502/1, 504, 504/1, 504gw, 507, 510, 510/1 (Fig. 3).

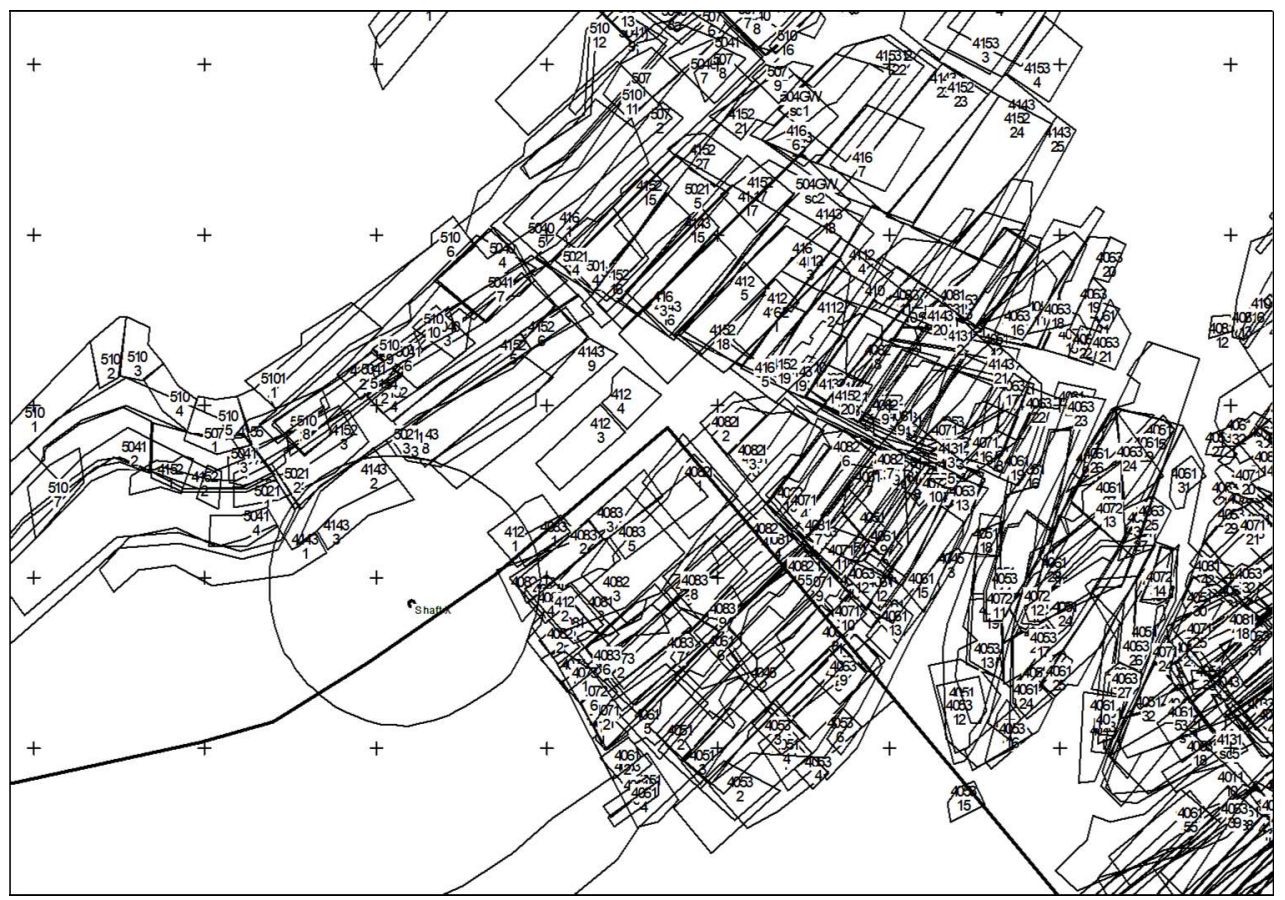

Fig. 3 Current mining longwalls in the area of shaft $X$

Mining operations were carried out mainly with the use of caving method and, to a lesser extent, using dry backfilling to the height from $0.81 \mathrm{~m}$ to $3.90 \mathrm{~m}$, at the depths from $245 \mathrm{~m}$ to $711 \mathrm{~m}$.

The carried out reprognosis of the impacts of the past mining operations in the area of shaft $X$ indicates that there may have been subsidence of approx. 
$30 \mathrm{~mm}$ on pit-bank level of the shaft, changes in slopes equal to approx. 0.65 $\mathrm{mm} / \mathrm{m}$ (category I), horizontal tensile strains reaching approx. $1.25 \mathrm{~mm} / \mathrm{m}$ and effective horizontal tensile strains, not higher than approx. $0.7 \mathrm{~mm} / \mathrm{m}$. These values fully validate the good technical condition of the lining of shaft $X$ and validate the absence of damage to the lining effected by the impact of mining operations to date.

\section{DETERMINING THE GROWING IMPACT OF MINING OPERATIONS OF LONGWALL No. 5 ON SHAFT $X$}

The prognosis of the impact of the exploitation of longwall No. 5 on shaft $X$ was carried out using the calculation programs (Białek, 2003), based on the theory of S. Knothe, W. Budryk, adopting the following values of parameters and coefficients :

- subsidence coefficient $-\mathrm{a}=0.9$;

- theory parameter $-\operatorname{tg} \beta=2.0$;

- proportionality factor $-\mathrm{B} / \mathrm{r}=0.32$;

- parameters determining the magnitude of the dissipation radius of influences in rock mass $-\mathrm{n}=0.665 ; \mathrm{z}_{0}=5 \mathrm{a} \mathrm{g}$;

- deviation coefficient of influences $-k=0.7$;

- fracturing factor for vertical strains $-S z=1.5$.

The rock mass deformations at the site of shaft $X$ were determined for the points located every $20 \mathrm{~m}$ along the axis of this shaft starting from the pit-bank level. The calculations were carried out for the face advance ranges of longwall No. 5, which increased every $50 \mathrm{~m}$ along its section running through the pillar of shaft $X$, starting from the moment when the longwall is $20 \mathrm{~m}$ from the western border of the pillar (it was labeled as range 1 mining of longwall No. 5). The deformations of shaft $\mathrm{X}$ were determined for 17 face advance ranges of longwall 5 (Fig. 4).

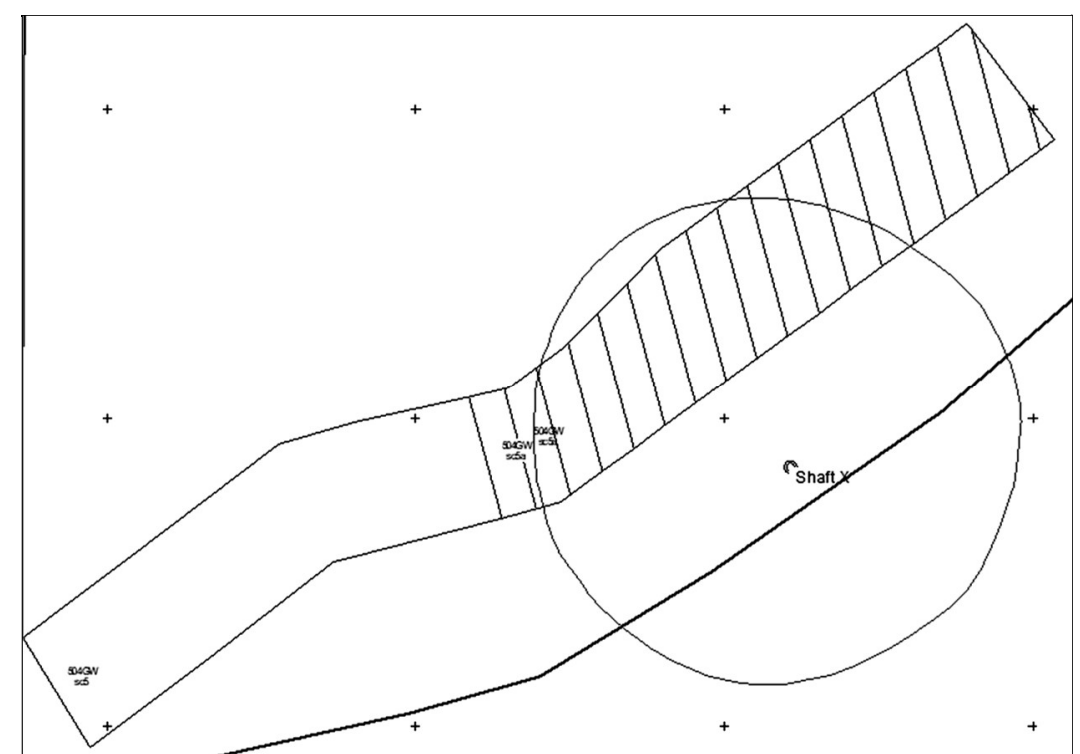

Fig. 4 Characteristic locations of the face advance of longwall 5 adopted for the calculations of mining influence on shaft $X$ 
Figures 5-10 show the development of the calculated basic deformation indexes for the selected ranges of face advance of longwall 5.

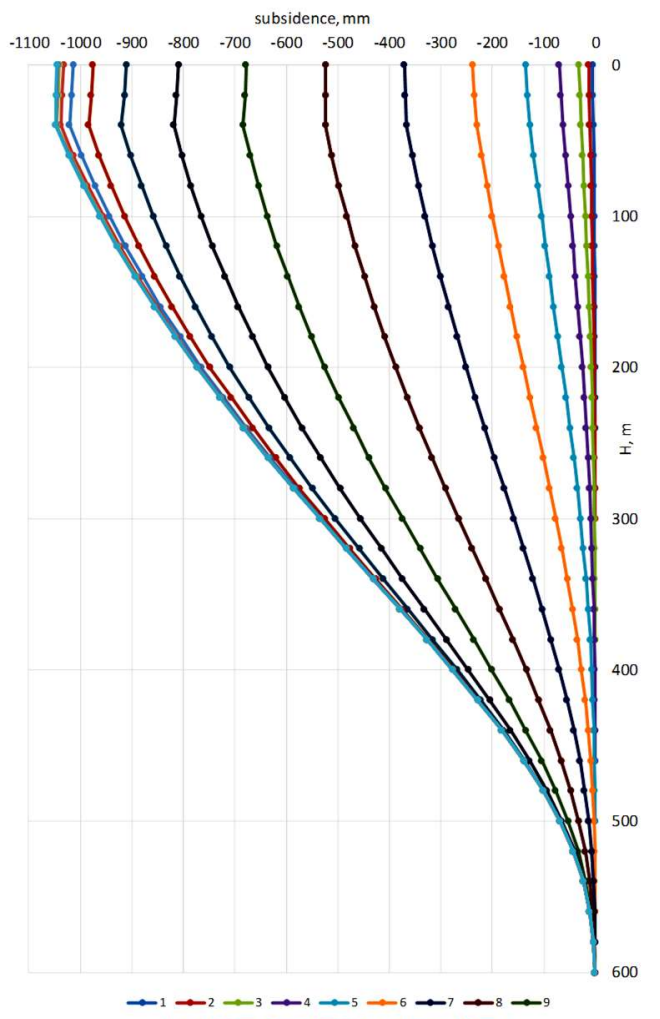

Fig. 5 Forecast subsidence in the axis of shaft $X$ for the selected values of face advance of longwall No. 5

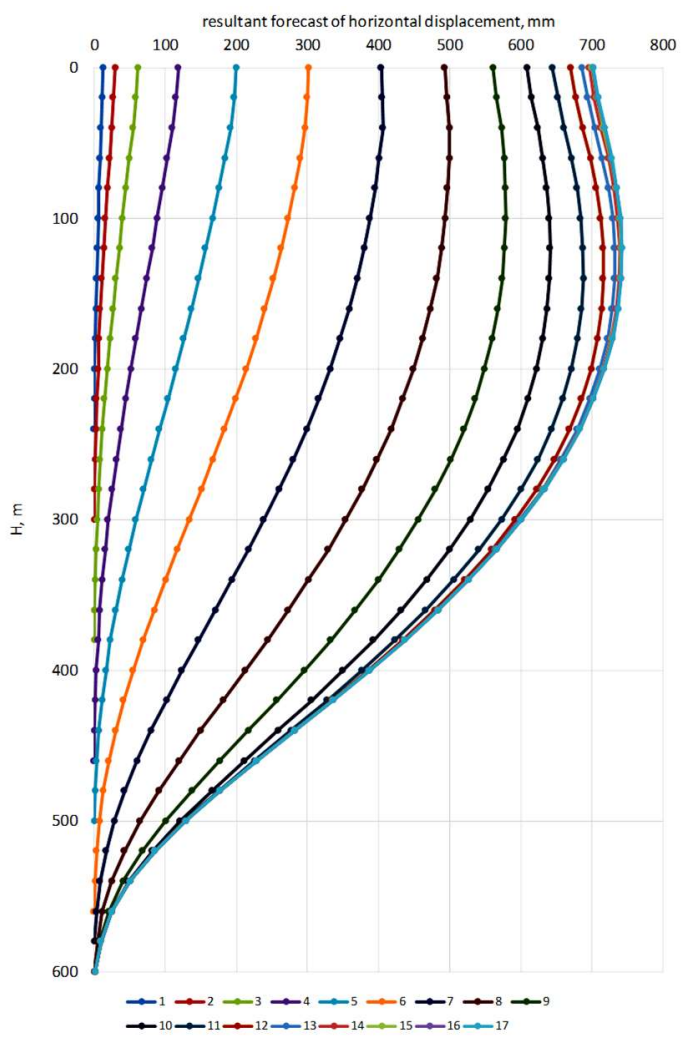

Fig. 6 Resultant forecast of horizontal displacement in the axis of shaft $X$ for the selected values of face advance of longwall No. 5 


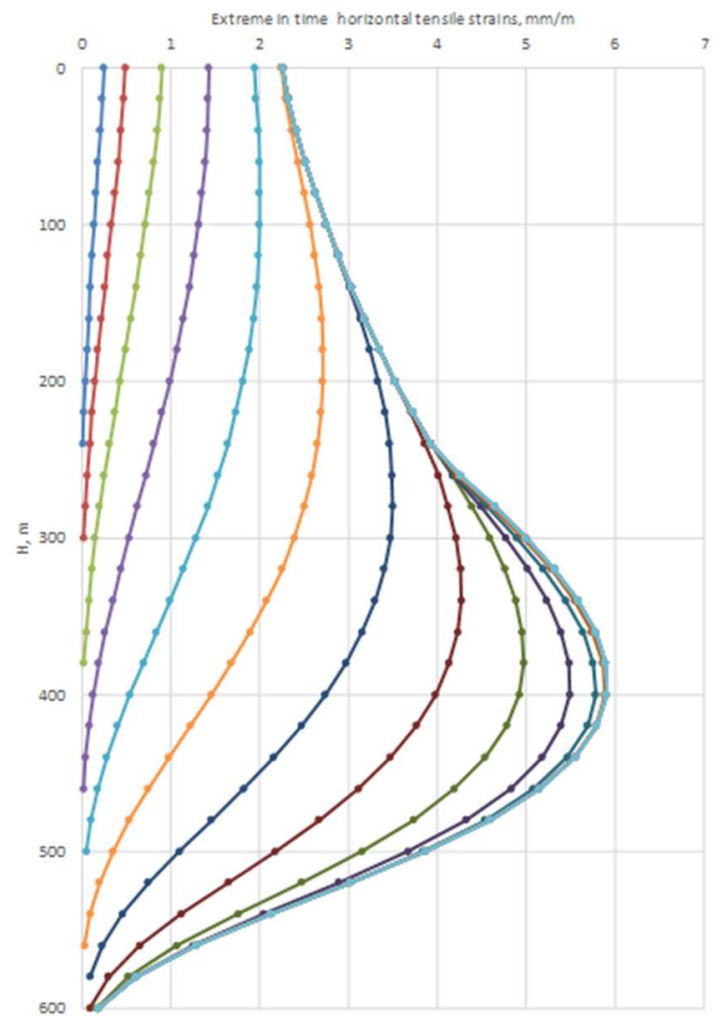

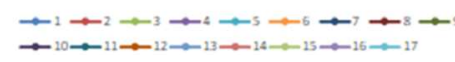

Fig. 7 Extreme in time horizontal tensile strains in the axis of shaft $X$ for the selected values of face advance of longwall No. 5

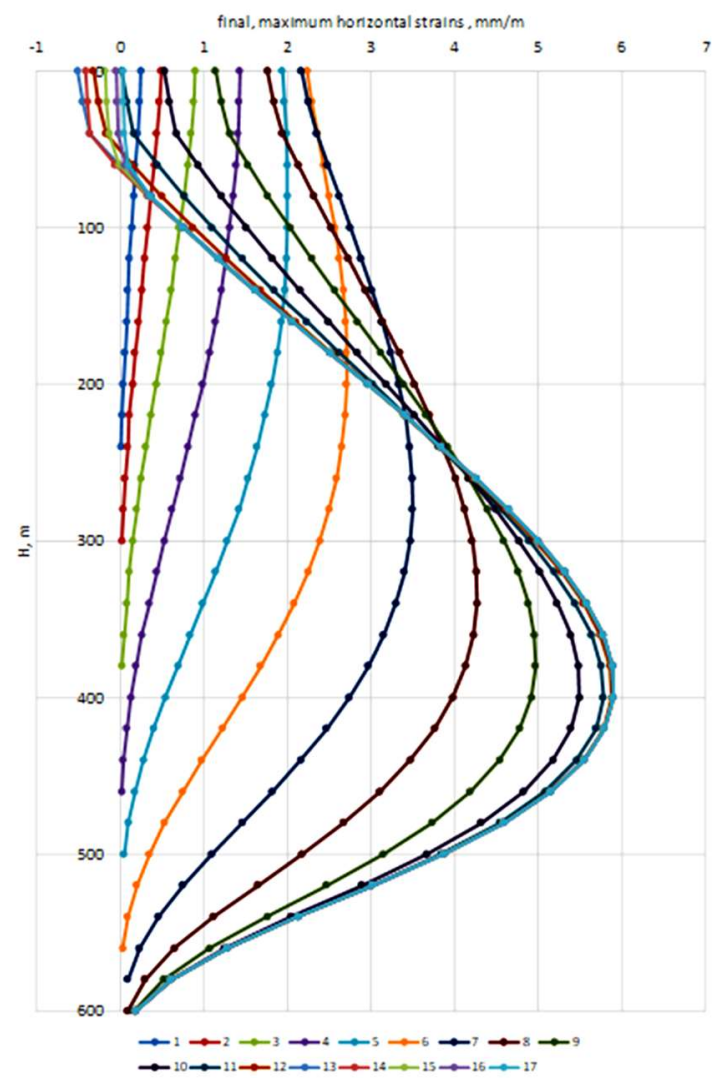

Fig. 8 Final, maximum horizontal strains in the axis of shaft $X$ for the selected values of face advance of longwall No. 5 


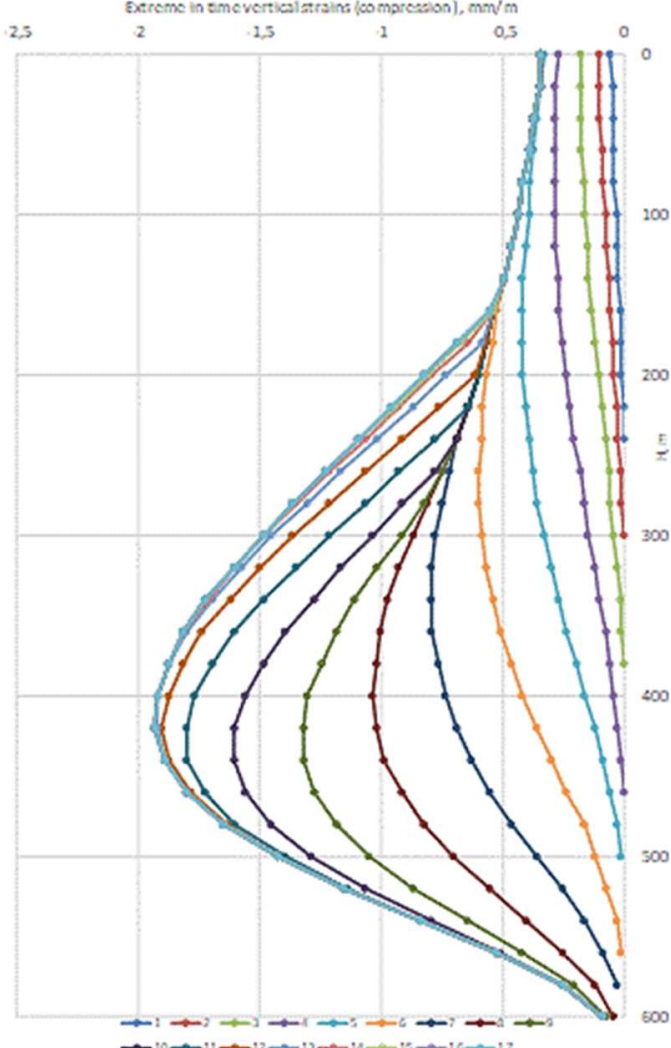

Fig. 9 Extreme in time vertical strains (compression) in the axis of shaft $X$ for the selected values of face advance of longwall No. 5

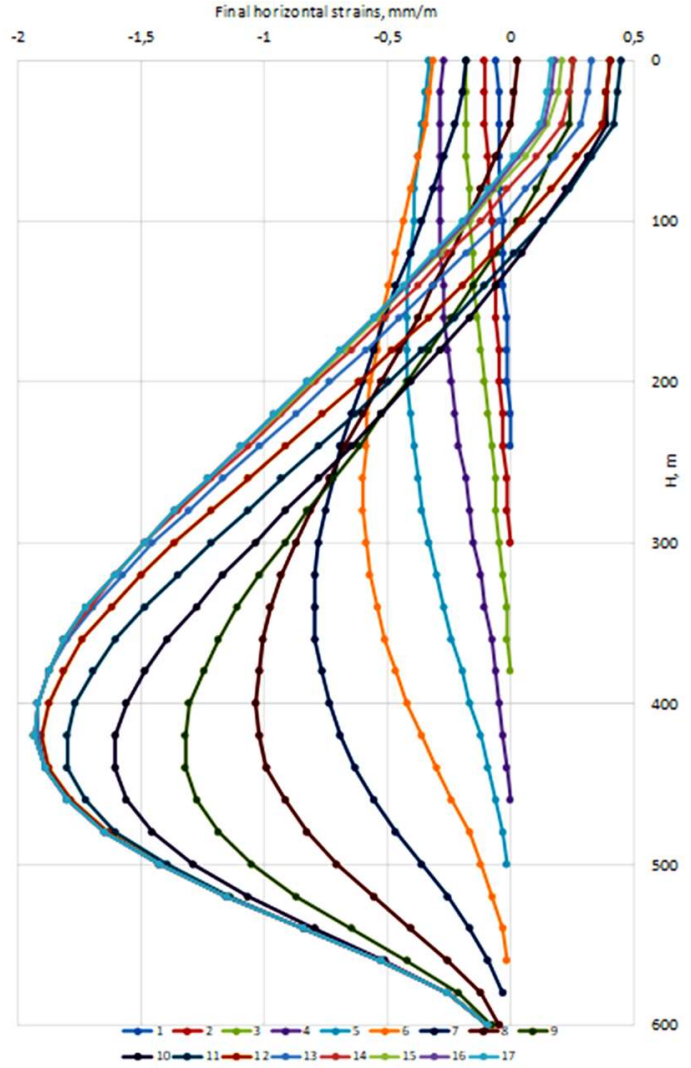

Fig. 10 Final horizontal strains in the axis of shaft $X$ for the selected values of face advance of longwall No. 5 
Based on the carried out prognostic calculations of the impact of mining operations of longwall No. 5 on the rock mass at the site of shaft X, we can state that for the range 1 , range 2 and range 3 , mining of this longwall will result in deformations which will comprise the sections of the shaft from the pit-bank level to the depth of $240 \mathrm{~m}, 300 \mathrm{~m}$ and $380 \mathrm{~m}$ respectively. For the remaining ranges of mining operations, the deformations will comprise the shaft column along its entire depth.

In the case when the mining of longwall No. 5 is completed for the face advance range 1 , the deformation of rock mass at the shaft site will be small, and their maximum values will be reported on the pit-bank level of the shaft, with the following values:

- subsidence - $5 \mathrm{~mm}$,

- resultant horizontal displacement $-13 \mathrm{~mm}$,

- final resultant slope changes $-0.11 \mathrm{~mm} / \mathrm{m}$,

- extreme in time horizontal tensile strains $-+0.25 \mathrm{~mm} / \mathrm{m}$,

- final vertical compressive strains - $-0.06 \mathrm{~mm} / \mathrm{m}$.

The exploitation of longwall No. 5 for the face advance 5 will also cause a slight increase in rock mass deformation at the site of shaft $X$. The maximum deformation values after the longwall 5 has reached the face advance 5 are as follows:

- subsidence equal to $135 \mathrm{~mm}$ - shaft section,

- resultant horizontal displacement equal to $200 \mathrm{~mm}$ - pit-bank level of the shaft

- final resultant slope changes equal to $2.74 \mathrm{~mm} / \mathrm{m}$ - pit-bank level of the shaft,

- extreme in time horizontal tensile strains equal to $+2.00 \mathrm{~mm} / \mathrm{m}$ along the shaft section from the depth of approx. $60 \mathrm{~m}$ to the depth of approx. $100 \mathrm{~m}$, and $+1.94 \mathrm{~mm} / \mathrm{m}$ - pit-bank level of the shaft ,

- final vertical compressive strains equal to $-0.42 \mathrm{~mm} / \mathrm{m}$ along the shaft section from the depth of approx. $140 \mathrm{~m}$ to the depth of approx. $200 \mathrm{~m}$, and -0.33 $\mathrm{mm} / \mathrm{m}$ - pit-bank level of the shaft.

With further increase of the face advance of the longwall No. 5 (face advance within the range of 6-10), the increment of rock mass deformation at the site of shaft $X$ will be now significant (especially in the lower section of the shaft), and when this longwall reaches the face advance range of 10 , the deformations will be as follows:

- subsidence equal to $524 \mathrm{~mm}$ along the shaft section from the pit-bank level to the depth of about $40 \mathrm{~m}$,

- resultant horizontal displacements equal to $500 \mathrm{~mm}$ along the section from the depth of approx. $40 \mathrm{~m}$ to the depth of approx. $60 \mathrm{~m}$, and $493 \mathrm{~mm}-$ pit-bank level of the shaft,

- final resultant slope changes equal to $4.86 \mathrm{~mm} / \mathrm{m}$ along the section from the depth of approx. $160 \mathrm{~m}$ to the depth of approx. $180 \mathrm{~m}$, and $4.30 \mathrm{~mm} / \mathrm{m}-$ pit-bank level of the shaft,

- extreme in time horizontal tensile strains equal to $+4.27 \mathrm{~mm} / \mathrm{m}$ at the depth of approx. $340 \mathrm{~m}$, and $+2.26 \mathrm{~mm} / \mathrm{m}$ - pit-bank level of the shaft , 
- extreme in time vertical compressive strains equal to $-1.04 \mathrm{~mm} / \mathrm{m}$ at the depth of about $400 \mathrm{~m}$, and $-0.34 \mathrm{~mm} / \mathrm{m}$ - pit-bank level of the shaft.

With the successive face advance ranges reached by the longwall No. 5 until the completion of the longwall (face advance range No 17), progressively smaller increments of rock mass deformation at the site of shaft $X$ will be observed. After the completion of the entire face advance of the longwall (face advance range No 17), the above deformations will have the following maximum values:

- subsidence equal to - $1048 \mathrm{~mm}$ along the shaft section from the pit-bank level of the shaft to the depth of about $40 \mathrm{~m}$,

- resultant horizontal displacements equal to $742 \mathrm{~mm}$ at the depth of approx. $120 \mathrm{~m}$, and $702 \mathrm{~mm}$ - pit-bank level of the shaft,

- final resultant slope changes equal to $7.78 \mathrm{~mm} / \mathrm{m}$ at the depth of approx. $220 \mathrm{~m}$, and $6.12 \mathrm{~mm} / \mathrm{m}$ - pit-bank level of the shaft,

- extreme in time horizontal tensile strains, equal to $+5.90 \mathrm{~mm} / \mathrm{m}$ at the depth of about $400 \mathrm{~m}$, and $+2.26 \mathrm{~mm} / \mathrm{m}$ - pit-bank level of the shaft ,

- extreme in time vertical compressive strains equal to $-1.94 \mathrm{~mm} / \mathrm{m}$ at the depth of approx. $420 \mathrm{~m}$, and $-0.34 \mathrm{~mm} / \mathrm{m}$ - pit-bank level of the shaft.

\section{DETERMINATION OF STRESSES IN THE LINING OF SHAFT X EFFECTED BY THE INFLUENCE EXERTED BY MINING OPERATIONS OF LONGWALL}

No. 5

When mining operations are carried out within the impact area on surface or underground objects, the extent and distribution of the impact of mining operations are particularly important in terms of safe operation of such objects (Drzęźla,1971, Mielimąka, 2009).

To determine the deformability of shaft lining, and thus to assess the possibility to take on the influences by shaft lining, the following factors must be allowed for in the first place (Hao et al., 2018, Kleta, 2013):

- horizontal strains of rock mass and lining,

- vertical strains of rock mass and lining,

- radius of curvature of the bent shaft lining.

Among the most important indicators that characterize rock mass deformations in the conditions of mining influence, the following should be mentioned (Chudek et al., 1971, Drzęźla, 1971, Huang et al., 2011, Kleta, 2013, Kleta \& Heyduk, 2015):

- vertical displacements and their derivatives:

- subsidence,

- vertical strains,

- horizontal displacements and their derivatives:

- horizontal displacements,

- deflection of the axis of (shaft) opening from horizontal displacements,

- curvature of the axis of the (shaft) opening . 
The assessment of the stability of the shaft which will be subjected to the impact of the proposed mining operation can be done in two ways.

The first method consists in adopting the basic assumption according to which the deformations affecting the shaft lining are compared with the calculated deformability of the shaft lining to take on a given deformation index, assuming that [Kleta, 2013, Mielimąka \& Kleta, 2019):

$$
\left|\zeta_{0}\right|>|\zeta|
$$

where:

$\zeta_{0}$ - calculated capacity to take on the deformation index by the lining,

$\zeta$ - rock mass deformation index, characterizing the impact of mining operation. The equation (1) can be also used to determine the computational strain capacity of the lining $\zeta_{0}$ to take on the value of a given deformation index, defined in the reprognosis, taking into account the measurement results of shaft deformation. The computational capacity to take on the deformation index by shaft lining can be defined as the strain capacity of the lining for a given deformation index.

In the shaft lining subjected to the impact of a deforming rock mass, vertical compressive or tensile strains develop, which are overlaid by the strains involving shaft column bending and horizontal strains resulting from the deformation of the diameter of the lining's support ring. When we consider the impact of longwall No. 5 on shaft $X$, two basic indicators of deformation are of primary importance, namely vertical strain $\varepsilon_{z}$ of the rock mass and the radius of curvature $R$ of the vertical axis of the shaft. The radius of curvature of the vertical axis of the shaft $X$ for the adopted characteristic face advance values of longwall No. 5 can be determined on the basis of prognostic calculations of horizontal displacements of the calculation points adopted in the axis of shaft $X$.

The components of the curvature radius of the shaft axis projection (on the planes $x, z$ and $y, z$ ) after its deformation can be expressed by the simplified relations (Drzęźla, 1971, Mielimąka \& Kleta, 2019):

$$
\begin{aligned}
& R_{x} \approx 1 / \frac{\partial^{2} u_{x}}{\partial z^{2}} \\
& R_{y} \approx 1 / \frac{\partial^{2} u_{y}}{\partial z^{2}}
\end{aligned}
$$

where:

$R_{x}, R_{y}$ - components of the radius of curvature of the line of vertical shaft axis, respectively in the direction of axes $x$ and $y$,

$u_{x}, u_{x}$ - components of horizontal displacement in the direction of axes $x, y$, $z$ - axis directed vertically.

The vertical stress in the shaft lining is in this case dependent on the vertical load coming from the vertical strain and from the curvature radius of rock mass, and the effects of these strains can be presented in the form of two internal forces, namely longitudinal force and bending moment. Vertical stresses in the cross-section of the shaft lining, treated as a bar on which simultaneously bending and compressive forces are acting, have the following form: 


$$
\sigma_{z}=\varepsilon_{z} \cdot E \cdot\left(1 \pm \frac{x}{\varepsilon_{z} \cdot R}\right)
$$

where:

$\varepsilon_{z}$ - vertical strain,

$E$ - modulus of elasticity of the lining material,

$R$ - radius of curvature,

$x$ - coordinate (Fig. 11).

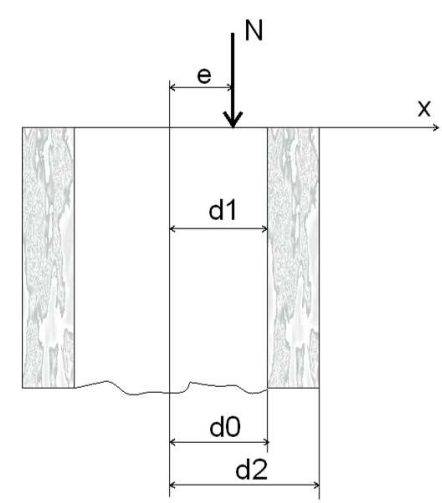

Fig. 11 Distribution of vertical stresses in the eccentrically compressed shaft lining ( $\mathrm{N}$ - longitudinal force acting on the eccentric $\mathrm{e}$ )

The case of eccentric compression (Fig. 11) is equivalent to the case of simultaneous bending and compression, and the longitudinal force $\mathrm{N}$ acts on the eccentric :

$$
e=\frac{M}{N}=\frac{i^{2}}{\varepsilon_{z} \cdot R}
$$

where:

$\mathrm{M}$ - bending moment,

$\mathrm{i}$ - radius of gyration of the cross-section.

In the cross-section of the shaft lining the following can develop:

- compressive stresses (for $e<\mathrm{d} 1$ and $e=\mathrm{d} 1$ ),

- tensile stresses (for $\mathrm{e}>\mathrm{d} 1$ ).

Fig. 12 presents the development of the calculated resultant vertical stress in the lining of shaft $X$ effected by the influence of the planned longwall No. 5 for the face advance range 5 and the termination of mining operations (face advance range 17).

The calculation results of vertical stresses in the lining of shaft $X$ for the face advance range 1-4 demonstrate that the vertical stresses along the entire length of the shaft do not exceed the permissible stress for a brickwork longwall lining (based on the measurements provided by the mine, permissible stresses of $32 \mathrm{MPa}$ were adopted). And the calculation results of vertical stresses in the lining for the face advance range 5 (Fig. 11) are similar in value to the permissible stress of the lining. Hence, in order to avoid damage to the lining of shaft $X$, the permissible face advance range 5 should be adopted for the longwall 5. To ensure no damage to the shaft lining is the basic condition for safe liquidation of the shaft. For this reason, it can be assumed that the liquidation of shaft $X$ by backfilling should be carried out when the face 
of longwall No. 5 reaches the face advance range 5 (the distance of the southeastern corner of the working excavation of longwall No. 5 from the shaft approx. $240 \mathrm{~m}$ to NWW) with prior stopping and disassembly of the winding plant.

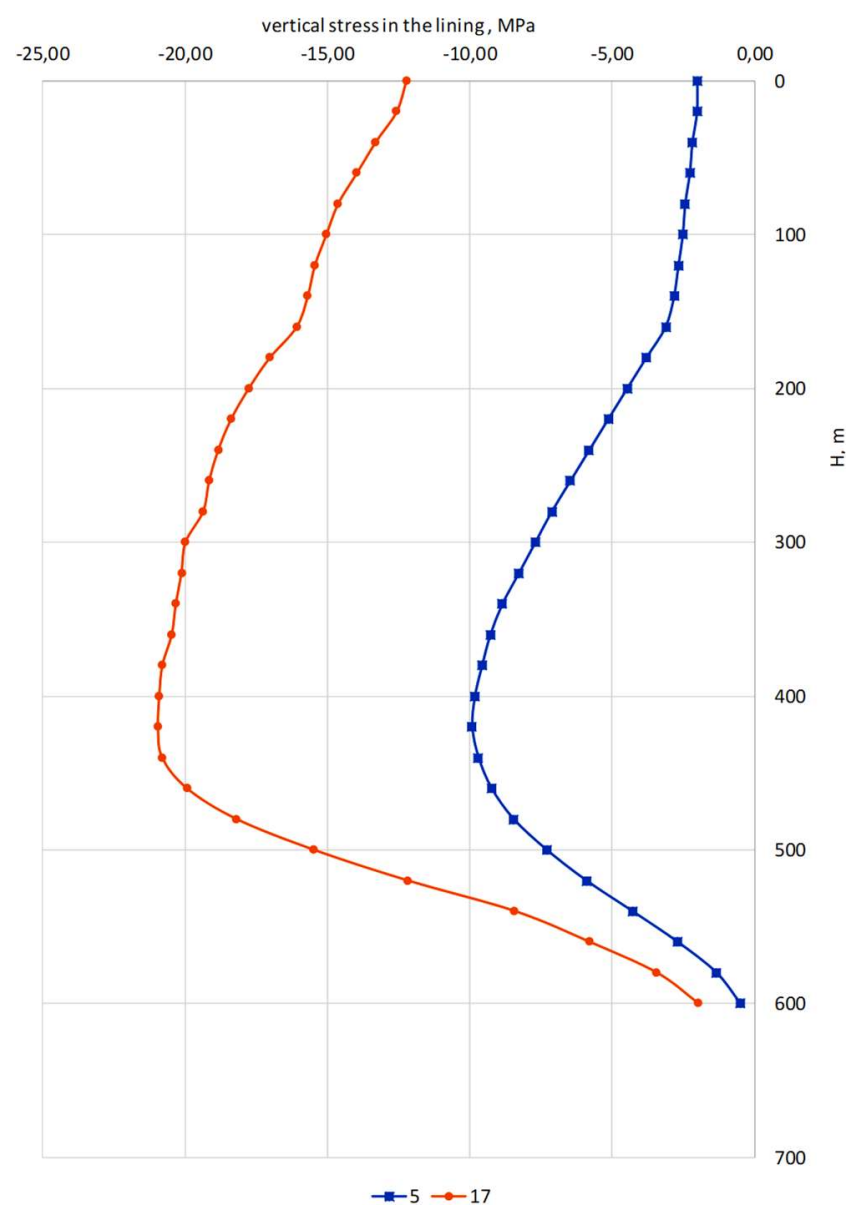

Fig. 12 Distribution of calculated vertical stress in the lining of shaft $X$ effected by the influence of the planned longwall No. 5 for face advance range 5 and face advance range 17

\section{SUMMARY}

The presented research subject involved the assessment of the possibility of mining operations within the area of shaft protection pillar with simultaneous liquidation of the shaft. In such a situation, the basic condition is to avoid damage to shaft lining, which can hinder or even prevent safe liquidation of the shaft by backfilling.

The procedure to follow in order to assess the possibility and scope of mining exploitation within the shaft protection pillar is demonstrated on the example of shaft $X$. In the area of this shaft, mining operation of longwall No. 5 is being carried out from west to east, which in its further course may pass from east to west through the protective pillar at the distance of approximately $175 \mathrm{~m}$ to the north from the shaft. Along with the exploitation of this longwall, preparatory activities are carried out for the liquidation of the shaft $X$ by backfilling it. Mining operations conducted in the protective pillar of the shaft will result in the development of deformations in the shaft, leading to its potential damage. Deformation of the shaft equipment may also bring about problems involving the 
functioning of the shaft's winding plant, and thus cause significant difficulties in the final preparation of the shaft for liquidation.

For these reasons, to ensure the safety of shaft $X$ until the liquidation time of the shaft by backfilling, it is necessary to coordinate the course of longwall 5 , the halt the shaft transport and the liquidation of the shaft by backfilling.

The applied assessment method involving the possibility and scope of mining exploitation within the protective pillar of the shaft was based on the forecast of rock mass deformation at the shaft site, which was the basis to calculate vertical stresses in the shaft lining and then to compare them with permissible values. The carried out calculations allowed us to determine the permissible face advance of longwall No. 5 at which no damage to the lining and its equipment would occur, ensuring the planned safe liquidation of the shaft by backfilling.

\section{REFERENCES}

Białek, J. (2003). Algorytmy i programy komputerowe do prognozowania deformacji terenu górniczego. Wydawnictwo Politechniki Śląskiej, Gliwice.

Chudek, M., Olaszowski, W. and Drzęźla, B. (1971). Obliczanie deformacji szybu pod wpływem eksploatacji. ZN Pol. Śl., s. Górnictwo z. 48, Gliwice, pp. 123-134.

Drzęźla, B. (1971). Poziome deformacje górotworu przy eksploatacji górniczej. ZN Pol. Śl., s. Górnictwo z. 44, Gliwice, pp. 25-40.

Hao, Y., Jixiong, Z., Sheng, Z. and Nan, Z.(2018). Physical modeling of the controlled shaft deformation law during the solid backfill mining of ultra-close coal seams. Bulletin of Engineering Geology and the Environment https://doi.org/10.1007/s10064-018-1335-1.

Huang, P., Chen, C. and Xiao, G. (2011). Feasibility Analysis on Using Shaft in the Region with Large Deformation. First International Symposium on Mine Safety Science and Engineering. www.sciencedirect.com Procedia Engineering 26 (2011) pp. 1726-1730.

Jaśkowski, W., Lipecki, T., Matwij, W. and Jabłoński M. (2018). Classical Measurement Methods and Laser Scanning Usage in Shaft Hoist Assembly Inventory. E3S Web

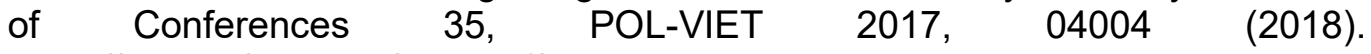
https://doi.org/10.1051/e3sconf/

Kleta, H. (2013). Zasady oceny bezpieczeństwa szybów i ich odporność na oddziaływania górnicze. Monografia, wyd. Politechniki Śląskiej, Gliwice.

Kleta, H. and Heyduk, A. (2015). Image processing and analysis as a diagnostic tool for an underground infrastructure technical condition monitoring. Underground infrastructure of urban areas 3. London: Taylor \& Francis Group, pp. 39-46

Mielimąka, R.(2009). Wpływ kolejności i kierunku eksploatacji prowadzonej frontami ścianowymi na deformacje terenu górniczego. Monografia, wyd. Politechniki Śląskiej, Gliwice.

Mielimąka, R. and Kleta, H. (2019). Prospects of mining operations in shaft protection pillars in terms of the assessment method of strain efficiency of their lining and calculations of rock mass deformation. Geoinformatica Polonica, Vol. 18, pp. 145155

Orwat, J. and Mielimąka, R. (2015). The comparison of measured deformation indicators of mining area with theoretical values calculated using Knothe's formulas. International conference of numerical analysis and applied mathematics 2015. ICNAAM 2015, Rhodes, Greece, 22-28 September 2015. Ed. Theodore Simos, Charalambos Tsitouras. Melville : AIP Publishing, s. 080014-1080014-4,

Orwat, J. and Mielimąka, R. (2019). Random dispersion of observed curvatures of mining terrain and measuring lines location relative to the exploitation edges. $19^{\text {th }}$ International Multidisciplinary Scientific GeoConference. SGEM 2019, 30 June - 
6 July 2019, Albena, Bulgaria. Conference proceedings. Vol. 19, Informatics, geoinformatics and remote sensing. Iss. 2.2, Geodesy and mine surveying. Photogrammetry and remote sensing. Cartography and GIS. Sofia: STEF92 Technology, pp. 267-275,

Qing, Y., Hideki, S., Takashi, S. and Kikuo M. (2012). Impact of Underground Mining on Shaft Lining and Aquifer in Eastern China. Open Journal of Geology, 2012, 2, 158-164 http://dx.doi.org/10.4236/ojg.2012.23016.

Xianzhou, L. and Weiming, W. (2018). Deformation Monitoring and Stability Analysis of Shaft Lining in Weakly Cemented Stratum. Advances in Civil Engineering Volume 2018, Article ID 8462746, 12 pages https://doi.org/10.1155/2018/8462746.

Zych, J. and Strzałkowski, P. (1987). Przemieszczenia i deformacje występujące w szybach pod wpływem eksploatacji górniczej. Metody i środki eksploatacji na dużych głębokościach (Wybrane zagadnienia). Wyd. Politechniki Śląskiej, Gliwice, pp. 243-262.

\begin{abstract}
.
The presented research subject involved the assessment of the possibility of mining operations within the area of shaft protection pillar with simultaneous liquidation of the shaft. In such a situation, the basic condition is to avoid damage to shaft lining, which can hinder or even prevent safe liquidation of the shaft by backfilling. The procedure to follow in order to assess the possibility and scope of mining exploitation within the shaft protection pillar is demonstrated on the example of shaft $X$. The applied assessment method involving the possibility and scope of mining exploitation within the protective pillar of the shaft was based on the forecast of rock mass deformation at the shaft site, which was the basis to calculate vertical stresses in the shaft lining and then to compare them with permissible values. The carried out calculations allowed us to determine the permissible face advance of longwall No. 5 at which no damage to the lining and its equipment would occur, ensuring the planned safe liquidation of the shaft by backfilling.
\end{abstract}

Keywords: impact of mining exploitation, shaft lining, deformation of the shaft mine shafts 